\title{
Life After Life-After-Life
}

\author{
Vincent Luciani \\ Northfield, New Jersey
}

\begin{abstract}
This essay is a first-person account describing the profound impact of my near-death experience (NDE). I surrendered everything in response to a spiritual mandate to do something different with my new life after the NDE. Researchers may find that such intensive responses contain credible data of interest in evaluating the question of why we have NDEs.
\end{abstract}

When formaldehyde came to my mind after I tasted my coffee that fateful morning, who would have guessed my taste assessment would ring true in only a few seconds? Sick for months, worse than suspected, a new ingredient had now suddenly been added to my life: death. I eased my aching body into a chair and then shakily lowered my cup. As though the cup, once it touched the table, were a magic switch, instantly a brilliant explosion of light went off in my head along with a brief release of energy. I was dead before I could cry out.

But not ultimate death. No, this was near-death, the momentary cessation of heart function. It was also when I experienced a mystical vision on a higher plane, the impact of which remains as powerful today as when it first happened. The story to follow is a synoptic sketch of that vision and my subsequent rebirth from a life as a conservative community member to that of an endless wanderer.

My collapse on March 25, 1985, had been preceded by three months of undiagnosed and progressively worsening muscular pains and

\footnotetext{
Vincent Luciani is a retired test engineer, writer, and traveler. Reprint requests should be addressed to Mr. Luciani at $218 \mathrm{~W}$. Revere Ave., Northfield, N.J. 08225
} 
spasms, all beginning with my usual winter's cold. So severe had the pains become that death was an envied option. Little did I know. What seemed like only an instant later I awoke in the hospital; actually, I had been unconscious for two hours. In that two hours, I (whatever "I" was) had been catapulted into a place alien to my Earth senses, whether beyond the cosmos or to the depths of my superconscious mind I do not know.

In describing near-death visions, Leon Rhodes wrote: "It would be difficult to think of an experience that is more private, secret, and personal than that brief, dramatic opening of the nonphysical eyes to another realm of consciousness" $(1990$, p. 71$)$. So it was, that first mysterious moment in eternity when my nonphysical eyes opened to a dramatic world of satiny blackness more total than is found anywhere on earth. I remember thinking this scene was not unlike being brought blindfolded into a friend's "otherworld" home. There was no fear, only calm acceptance and an eager, almost childlike anticipation of the drama surely about to unfold.

On an unending table was a large, newspaper-sized book. This was the legendary book of akashic records that exists for every soul. Within each book is said to be recorded that soul's every thought, word, and deed dating from the soul's very beginning and from all existences in this and other worlds. The pages of my book soon unfolded on their own, reverse from the normal direction, to reveal my entire life's every detail chronologically in three-dimensional living color. This fascinated me, even there, as I observed and absorbed half a century of life in a mere ten seconds of equivalent Earth time. My neglects were disappointingly apparent from the review; more dismaying, however, was the realization that my goal from this Earthwalk had not been accomplished.

A figure standing off to the side observed my reactions. Biblical in appearance, Earth-age perhaps mid-fifty, his presence was magnificent: robes, hands, face, neatly trimmed beard all luminesced a blinding whiteness twenty times more brilliant than our sun's light. Instinctively I raised a hand as a protective shield, but my mind received. quick assurance that sight in this place was not by Earthly eyes but by impervious nonphysical eyes. Wonder upon wonder!

I was embarrassed at my life's failures and eager to apologize, but my new friend made it apparent he already knew not only the whole of my current life situation but also my soul's every moment since the time of its creation. I, in turn, knew - at least for the moment-his identity, his thoughts, his spiritual existence. And so we talked in a manner suggestive of mental telepathy except more total, nothing held back. But 
what could be held back? We shared all that was each other's past, present, and future.

The intimacy of sharing another's totality is the very essence of infinite love. Of the many who experience near-death's spiritual encounter, some offer vivid accounts of exotic experiences, while others speak only of a radiant light, the Light of God. Yet whatever their vision, near-death survivors are forever changed by coming to know infinite love. Afterward, readjustment to Earth ways becomes a challenge for most, difficult for some, impossible for a few.

Lengthy discussions with my new (old?) friend followed. When we finished, I logically rationalized that my life had been largely negative, that for me to terminate without having accomplished my goals would render its stresses in vain. I therefore asked to be returned for another try.

"But it will be difficult for you," he cautioned.

Knowing well his meaning, I bargained: "Then will you send the woman to help me?" At the time, her identity seemed obvious.

"The woman shall come to help you," he promised. And then I awoke in the hospital.

My first view in the emergency ward was of wall-to-wall biomedical equipment with flashing lights and displays, and no one in sight. Considering that only an instant earlier I had been in my own kitchen, that deep within me was a vague awareness of having also been to the outer fringes of the universe, and factoring in an alien array of life support and monitoring devices to which I was now connected, can anyone doubt my reasoned conclusion? I fully believed I had been abducted by a UFO!

A doctor soon appeared to explain the tests they were doing. Weakly murmuring, "Don't bother; just get the blood test results," I pointed down the hall and promptly again lapsed into unconsciousness. Coincidentally, this hospital was where I had gone for a diagnostic blood test only two days earlier. Test results showed the collapse had been caused by a severe calcium deficiency. In contrast to a normal serum blood level of 8.5 to 10.5 milligrams per deciliter, mine registered 1.1, and perhaps had been zero at the time of my collapse. Heart muscles must be constantly bathed in serum calcium with every stroke in order to continue functioning. The pains left and have never returned, nor have I ever again had a cold after that episode.

Upon returning home a few days later, endless questions filled my mind about whatever in the world (or out of it) had happened to 
unhinge me so spiritually. I had never heard of near-death experiences. Nothing from a lifetime of formal religion had either prepared me for or protected me from the emotional fallout from this event. To have had another near-death survivor on hand, someone to listen knowingly and acceptingly to the litany of impossibles then gnawing at my fractured ego, would have made a significant difference. My pastor tried, as did a few others. All, including my then-wife, simply were unable to accept such improbable tales of supernatural journeying from an ordinary person they had known for so many years.

Trauma then added to trauma when pieces of the puzzle came up missing. Identities of those in the vision, and the goals for which I had returned to life were now blocked from recall. Remaining was only a constant subconscious buzz of answers, all forever on the verge of popping into my consciousness but never quite succeeding. Imagine my frustration when intuitively I knew I should be somewhere doing something urgent but I couldn't remember what.

My nightly dreams thereafter became vivid and dramatic. In order to capture their content, I trained myself to awaken every ninety minutes following a rapid eye movement (REM) dream period. So successful did this habit become that even now my sleep comes in spurts of exactly one or two or at most three REM cycles. Months later, recurrent dream messages formed a pattern. My first moments awake would often be filled with pleasant memories of having been somewhere distant, or having helped those who awaited me. Although no individual dream stood out from the others, their cumulative impact left me with little doubt that higher forces were directing me to leave, to go in search of whatever was to be seen or found or created "out there."

I procrastinated for two years. Ultimately, unrelenting pressures from both my dreams and my waking life events climaxed in what surely must have been a divinely orchestrated affair, one where the unremembered spiritual collaboration of three years earlier was accepted. I surrendered everything of my old life-so easily said in so few words!-in June, 1988, and set out for parts unknown. I have been traveling ever since.

My travels soon ranged 40,000 miles outside the country and as many more by car throughout the United States. There was first my return to the sea I had sailed in my youth, with voyages to West Africa, then a trek to visit relatives in Italy I had never met, and a year later to the opposite corner of the globe to New Zealand and Australia.

In early 1989, while I was in North Carolina, a spiritual friend who knew what had happened to me gave me a magazine article, "Sur- 
viving the Near-Death Experience," by P. M. H. Atwater (1989). Finally I learned of kindred spirits who had reactions like mine to their exclusive moments in eternity. I found out that it was not unusual for experiencers to develop an almost irrational need for classical music. I discovered why animals now come to me, including cats, which in my "former life" I had distrusted and disliked; one of my favorite photos is of a wild white dove perched on my shoulder as if tame. I also learned not to be alarmed at suddenly "remembering" the future, not to care about money, except for enough to get by and some to give away, and not to be surprised if I sometimes feel or see the gist of what people really think when that differs from what they say. The list of quirks normal for near-death survivors is lengthy.

Inspired by Atwater's writings, I launched my Appalachian Odyssey, a random series of wanderings by car that became a 12,000-mile, sixmonth journey throughout a dozen states from New York to Georgia and from Indiana to Virginia. During this period I sampled life in ashrams, communes, farms, retreat centers, and private homes, although mostly in motels.

Lacking a "how-to" manual on proper wandering, I simply sought out new places, new people, and new experiences. I touched the lives of those who did not know where their next meal was coming from, and sampled a variety of religions in my need to observe how others worshipped their God. My inner guidance, as it turned out, rendered any how-to manual quite unnecessary. Each day's travels would begin when I gave my car its rein, sometimes almost literally. There were times when my idea to reach one destination, for example, would quickly change because I missed a critical turn-off, so my car would simply continue on to another destination, where I would find myself giving assistance, perhaps by gardening or helping people move their households.

Many times these detours guided me to meet people uncertain of their spiritual nature. I'd simply listen to their eager thoughts, then hear them say, "T've never told anyone this before," or "I don't know why I'm telling you all this," or the ultimate, "Thank God you came along!" Hobbit creator J. R. R. Tolkien wrote:

All that is gold does not glitter,

Not all those who wander are lost. (1965, p. 231)

Indeed, I never felt lost, no matter where I wound up. Rather, my life seemed strangely "on schedule."

I gave many of my new friends a copy of the Peace Pilgrim pamphlet 
I carry in quantities. Peace Pilgrim (her assumed name) walked 25,000 miles across the United States for the cause of peace, especially inner peace. Although she eventually became a celebrity, she chose to continue walking, alone and penniless, until her death in 1981. Her Earth presence continues via the book of her writings and in my daily life.

These journeys were magical to me, as if a radio station in the sky were broadcasting my presence. People everywhere, even other wanderers, spontaneously recognized my needs and responded to them, and I to theirs. A typical example of this was the time I drove into a Virginia city the day before university graduation, and discovered all the motel rooms filled. By whatever guidance, my car stopped at a muffler shop, an unlikely place to ask for lodging. Yet despite being busy, the manager, two employees, and two customers were soon competing to find me a room. It didn't take long before I had what I needed.

To cite another example, unfurnished apartments are unlikely places for me to stay, traveling as I do with only what I can pack into my car. Yet twice I have signed leases for unfurnished apartments. In South Carolina, an apartment manager generously brought in nearly as much furniture as he provided in his furnished units. In New Mexico, other tenants loaned me a bed, blankets, desk, chairs, tables, lamps, bookcases, and more. While these examples may not be spiritually powerful, daily repetition of such events seemed to reflect divine guidance.

Despite all this kindness, however, there were unexpected problems, learning experiences, that I came to appreciate like the thorns that come with roses. Generosity from others, I learned, resulted only when there was a "mission" or a job I could perform for them. If I put my own needs ahead of service, things would go wrong. Never perfect in my "former" life, I am keenly aware of being less so in this stage of my life.

It seems as if Peace Pilgrim were writing just for me when she wrote (1982, p. 59$)$ :

The purpose of problems is to push you toward obedience to God's Laws, which are exact and cannot be changed. We have the free will to obey them or disobey them. Obedience will bring harmony, disobedience will bring you more problems.

Aside from this, however, were the numerous times when "spirit" took over and I would have an opportunity to learn a special lesson. Once, in the mountains of West Virginia, my car raced out of control at a sharp downhill curve with no guardrails. With so distressingly limited a future at hand, I turned to God; we pray so beautifully in such 
moments, do we not? With my hands off the steering wheel, I yielded to the Infinite and watched in stunned fascination as the car sailed slightly out over a ravine then neatly turned back on track.

Utah's lonely highways set the stage for a similar situation when I foolishly began reading a map while cruising at top speed. Suddenly a superphysical force struck my wrist, knocking my driving hand from the steering wheel. Looking up, I panicked to see I was on a collision course with a concrete bridge rail. Once again there was divine intervention and my car reacted on its own, swinging back on course so sharply no human could have made the maneuver without rolling the car. There have been so many "car saves" to compensate for my distracted driving that I am convinced one day my transition will come while I am in a car.

Car situations were not my only encounters with spirit. Honolulu was the scene of another sort of dramatic protection. This incident took place in pre-dawn darkness at my unattended back-alley hotel, neither the time nor place to be alone, especially after a gang had gathered across the alley. I needed to walk past them to reach the curb on the other side or miss my limousine ride to the airport. Opening my Peace Pilgrim book with shaking hands, I read:

If you have a loving attitude toward your fellow human beings, you will not fear them: "Perfect love casteth out fear." An obedient attitude toward God will bring you into the constant awareness of God's presence, and then fear is gone. When you know that you are only wearing the body, which can be destroyed-that you are the reality which activates the body and cannot be destroyed-how can you be afraid? (1982, pp. 160-161)

From my first introduction to her life only months earlier, I felt an immediate rapport with the Peace Pilgrim spirit. Now comforted, although still apprehensive, I walked hand in hand with her spirit to the curb where we sat down to wait. Nothing happened; the gang, only twenty feet away, ignored me, without even a glance. It was as though I were invisible. When the driver arrived, a hulking bruiser, I welcomed his presence as if he were the Archangel Michael. (And who can say that he wasn't?) Even so, at the airport he admitted having been concerned about picking up a passenger in the isolated darkness of that chancy place.

The Edgar Cayce Center at the Association for Research and Enlightenment (A.R.E.) in Virginia Beach was where I fittingly closed out my Appalachian Odyssey in the fall of 1989. This was Mecca for one like myself who so totally accepts the late psychic's description of how 
to live a spiritual life; his spirit seems to prevail there, decades after his death. This is also the place where a special friend introduced me to the works of Peace Pilgrim, and where a series of consecutive trance dreams illuminated much of my 1985 near-death vision.

These dreams identified the Biblical figure in my near-death experience as the Archangel Michael. Although his existence was not a prominent part of my religious background, I now will not go to sleep without first invoking his protective presence, a practice that has thankfully made rare the screaming nightmares that at times used to haunt my sleep. Through this dream process, I also remembered multiple near-death visions that had occurred during the first day I was hospitalized back in 1985, when I had drifted in and out of consciousness. Few of the details were revealed, but I was given the understanding that one day all of it will be released into my conscious mind.

Some facets of my 1985 near-death vision did become clear. As one example, during the public lectures I began to deliver from 1990 on, I referred to my original vision as being entirely in black and white, even though my life review was in "three-dimensional living color." At some level I always knew of the color, yet it had been impossible for me to recall this simple truth consciously. This selective inhibition of details of my near-death vision resembled that of a posthypnotic suggestion. While talking to a UFO group in Utah the following year, however, someone asked a related question and, as though a door to my mind's inner sanctum had suddenly opened, I could now see the living color of my life review so obviously that the earlier restraint had become incomprehensible.

This process of subconscious release continues, wherein bits and pieces of new information are regularly revealed to my conscious mind, usually when least expected, sometimes via writing when my mind is pressured to yield another of its secrets. And always, the sensation is much the same as reading a telegram for the second time: that is, an acknowledgement of what I had already known. I have no other words to explain this phenomenon, nor do I understand it any better now than I did that day in Utah. This mechanism brought to my mind an image from my near-death vision of myself as a young man clad in a toga from the Phoenician period of about 4000 B.C., kneeling on my left knee. My next day's research at the A.R.E. library turned up a drawing from the Phoenician culture of a toga-clad youth kneeling on his left knee, a Phoenician mark of respect toward an elder.

During these visions, I had ongoing discussions with the Archangel Michael. Cradled in one of my arms was a loving object which, although I clearly knew its spectacular identity, I was unable to ac- 
knowledge until now. My dreams revealed that it was a lamb, the exquisitely magnificent presence of Jesus made manifest as the Lamb of God. Though it is impossible for me to speak of this without tears, it is my fond desire to face one day a group of caring souls who will press me with question after question about the Lamb until the pressure helps me to release the hidden message behind that symbol.

My visions also included levitation; the healing of children; instant transport to any destination, whether terrestrial, extraterrestrial, or otherworldly; and an escorted tour of the universe in which all knowledge was freely made mine. At the end, I suggested three times that it would be wise for these powers to be blocked from memory before my return. Only after my third request did the other beings react. I don't know why they seemed intent upon returning me in full possession of such supernatural graces; perhaps they were testing my self-centered ego, to see if I would pass the test.

I was also able to recall two tall, thin figures who stood mutely behind Archangel Michael in my original vision, neither of whom ever moved or spoke. These were twin souls, presumably myself and another, both frozen in action by virtue of our spirits being locked in the Earthplane. How puzzling that "I," my ego, was observing "me," a Phoenician youth, who was in turn looking beyond Archangel Michael to my "self" in a third form.

These dreams also clarified that the woman promised me was my twin soul, and to find her was my new mission. She fairly exploded into my life January 27, 1990, but not in three dimensional form. Her visit came at the above-mentioned hotel in tourist-jammed Honolulu. Arriving after a long, sleepless flight from Western Australia, discouraged and exhausted, I struggled into my room, flung my luggage on the floor, and went directly to the bedroom where I literally collapsed. Instantly I entered a deep sleep or trance. She immediately appeared, not as an apparition but of the same substance I was at the moment, radiantly joyful that our Earth presences were geographically closer. Our spectacular joining that day often serves as an anchor to help me ground myself, proof to my doubting-Thomas mind that she really does exist here on Earth, likely in the United States.

We shared much, and then she abruptly left. Awakening with her lingering presence powerfully filling my senses, I foolishly ran out the door calling for her, but she was gone. Perhaps in consolation, perhaps in confirmation of our oneness, we met in ethereal form several more times over the next thirteen months. Despite these meetings, few of her physical features remain in my mind except for her calming eyes. 
Since then I have seen women with similar eyes several times, and each time I find myself asking in spirit, "Are you the one?" There was the vitally dynamic woman in Colorado in March, 1991, who repeatedly said, "Welcome home," but then refused further contact. And there was the petite woman from Maryland named Cindi. We were guided to meet at a Route $\mathbf{4 0}$ roadside tourism office in New Mexico, where we talked perhaps 15 minutes. Sadly, I uncharacteristically stumbled over everything I said to her, stunned as I was by my sudden recognition of her, a recognition she did not reciprocate. When she left for Albuquerque, I had neither her name nor her address. Was she really the one? and if not, what was I supposed to learn from this?

What, if anything, have I gained from my wandering? I now have a keen acceptance of our need to share with each other and help each other whenever we can. Giving is how we manifest love, God's greatest law: "As you did it to one of the least of these my brethren, you did it to me" (Matthew 25:40). Although not everyone needs to volunteer to serve with Mother Teresa (and why not?), there are thousands of wanderers-not drifters but seekers-of all ages, means, and talents throughout the world who serve wherever they are needed, taking nothing in return except perhaps food and a sheltered bed.

Those who are materially comfortable might ask themselves whether so many possessions are theirs to own or God's to loan. We all need to "put some back" while there is time. We should be giving willingly and eagerly from our very needs, not just from our surplus, which long ago should have been given away: "He who has two coats, let him share with him who has none" (Luke 3:11). Furthermore, what we give with no one knowing about it except God counts the most at our inevitable life review at death. And finally, giving also has a corollary in receiving, in not protesting when offered help. Virtue also extends to allowing others their opportunity to acquire grace by serving you.

What was the elusive goal I was propelled back into life to fulfill? Peace Pilgrim had written (1982, p. 8): "When the God-centered nature takes over, you have found inner peace. Until that time, a partial control can be gained through discipline." And there's the rub, the disciplinary struggle within for control of the ego. This is what Archangel Michael meant would be so difficult the second time through.

Times and people have changed. Although my wanderings continue, the stopovers now measure months rather than days, in California, Texas, Florida, South Carolina, Colorado, Montana, and New Mexico. Nor are the spiritual contacts as frequent or as daring or exciting as 
before. Instead, a tiredness has set in, not so much a physical one-I eat only natural foods, take supplements and exercise-nor a spiritual one, not after having so often experienced God as a friend.

No, it is more a mental fatigue from remaining balanced on a lifelong tightrope stretched between two lives and two worlds. I feel stalled, too far along to turn back to the old ways of my self-centered ego, yet unable to relinquish the past fully in order to achieve Nirvana, the God-centered goal of the opposite shore. I pray now more than ever, yet my prayers seem only to trigger responses of "Stride on; everything ever needed or desired is straight ahead." Peace Pilgrim wrote (1982, p. 8): "During the spiritual growing up period the inner conflict can be more or less stormy."

Offsetting the self-centered ego's sensory gratifications, which trapped us into the Earth cycle to begin with, is the inner illuminating beacon most simply called "Mind Within." Cayce, from his otherworld vantage, often referred to mind as "the builder"; researchers have said that near-death experiences are "all in the mind." Both may be right. Imagine a near-death scenario in which the mind, the governing center of all we are, becomes alert to the threat of death but aware that this will not truly be the final exit. In order to avert an unscheduled transition, the mind creates a near-death vision as a diversionary tactic, enabling the physical self to continue idling until medical assistance arrives.

Atwater has written knowingly (1988, p. 174): "The near-death experience is a teaser, an introduction to what lies 'beyond' and a second chance at life.... It is an opportunity!" Although all near-death survivors are called to serve, few respond. Perhaps for those who, as a result of their near-death experiences, are later motivated to serve, the mind had generated a mystical encounter whose power is proportional to the immediacy of the threat of death. That is, the greater the possibility of death, the more powerful the vision and the more intimately bound one forever becomes to its hold.

Melvin Morse and Paul Perry (1990) described the work of neurosurgeon Wilder Penfield, who had established an area of the brain along the Sylvian fissure that, when electrically stimulated, caused some patients to experience visions of God, to hear heavenly music, to see dead relatives, and to have a life review. Yet we who have enjoyed our own unique moment in eternity will defend to the final breath our absolute conviction that our visions were very real.

Can we have it both ways? Can the vision be real and yet all in the mind? It can if we accept that our minds can create our reality. That is, you who now read my writings are resident in my universe, and I who 
wrote these words am resident in your universe. Your universe and mine are uniquely separate yet emphatically one and the same. "The human mind is the extension of God-Mind. In fact, there is but one Mind," wrote Philip White (1991, p. 64). "Nor will they say, 'Lo, here it is!' or 'There!' for behold, the kingdom of God is in the midst of you" (Luke 17:21).

When next the bell tolls for me, I will likely review my second-life's wanderings with much the same logic as before, though perhaps anticipating a more deserving grade on my report card. Heaven forbid, literally, that I should ask for another try. Until then,

All my thoughts to heaven are turning,

For the world I have no yearning.

Though I wander hither, yonder,

Evermore I ask me now:

Man, ah Man! Where goest thou?

(Johann Sebastian Bach, Cantata No. 166)

\section{References}

Atwater, P.M.H. (1988). Coming back to life: The after-effects of the near-death experience. New York, NY: Dodd, Mead.

Atwater, P.M.H. (1989, January/February). Surviving the near-death experience. New Realities, 9(3), 14-19 \& 48-51.

Morse, M., and Perry, P. (1990). Closer to the light: Learning from the near-death experiences of children. New York, NY: Villard.

Peace Pilgrim [Norman, M.]. (1982). Peace Pilgrim: Her life and work in her own words. Santa Fe, NM: Ocean Tree Books.

Rhodes, L.S. (1990). The near-death experience: Public or private? Journal of Near-Death Studies, 9, 71-75.

Tolkien, J.R.R. (1965). The lord of the rings. Part l: The fellowship of the ring. New York, NY: Ballantine.

White, P. (1991, December). Editorial. Unity Magazine, p. 64. 